\title{
A combination of tyrosine kinase inhibitors, crizotinib and dasatinib for the treatment of glioblastoma multiforme
}

\author{
Hayley Nehoff ${ }^{1}$, Neha N. Parayath ${ }^{1}$, Melanie J. McConnell ${ }^{2}$, Sebastien Taurin ${ }^{1}$, \\ Khaled Greish ${ }^{1}$ \\ ${ }^{1}$ Department of Pharmacology and Toxicology, University of Otago, Dunedin, New Zealand \\ ${ }^{2}$ School of Biological Sciences, Victoria University of Wellington, Wellington, New Zealand \\ Correspondence to: \\ Sebastien Taurin, e-mail: sebastien.taurin@otago.ac.nz \\ Keywords: glioblastoma multiforme, tyrosine kinase inhibitors, invasion, Met, SRC \\ Received: April 23, $2015 \quad$ Accepted: October 06, $2015 \quad$ Published: October 16, 2015
}

\section{ABSTRACT}

Glioblastoma multiforme (GBM) is the most common and aggressive primary brain tumor. Despite the advances in surgery, radiotherapy and chemotherapy, patient survival averages only $\mathbf{1 4 . 6}$ months. In most GBM tumors, tyrosine kinases show increased activity and/or expression and actively contribute to the development, recurrence and onset of treatment resistance; making their inhibition an appealing therapeutic strategy. We compared the cytotoxicity of 12 tyrosine kinase inhibitors in vitro. A combination of crizotinib and dasatinib emerged as the most cytotoxic across established and primary human GBM cell lines. The combination treatment induced apoptotic cell death and polyploidy. Furthermore, the combination treatment led to the altered expression and localization of several tyrosine kinase receptors such as Met and EGFR and downstream effectors as such as SRC. Furthermore, the combination treatment reduced the migration and invasion of GBM cells and prevented endothelial cell tube formation in vitro. Overall, our study demonstrated the broad specificity of a combination of crizotinib and dasatinib across multiple GBM cell lines. These findings provide insight into the development of alternative therapy for the treatment of GBM.

\section{INTRODUCTION}

Glioblastoma multiforme (GBM), a grade IV astrocytoma, is the most frequent and aggressive malignant primary brain tumor with a 5-year survival rate of 5\% [1]. GBM is principally idiopathic, although several genetic mutations, epigenetic variations, viral infections and environmental factors have been identified as potential risk factors [2-5]. The standard treatment for GBM involves surgical resection and radiotherapy with concomitant and adjuvant temozolomide administration [6]. Despite the three-pronged treatment strategy, relapse is universal. The limited efficacy of the current treatments is partially a consequence of the heterogeneity of the tumour cell population. GBM is classified into four subtypes, the classical, mesenchymal, proneural and neural subtypes all characterised by distinct transcriptional profiles [7]. The subtypes are associated with the amplification and/ or mutation of several receptor tyrosine kinases (RTKs) such as the hepatocyte growth factor receptor (Met), the platelet-derived growth factor receptor (PDGFR)- $\alpha$ and epidermal growth factor receptor (EGFR) in the mesenchymal, proneural and classical subtypes, respectively [7]. Furthermore, recent studies have also confirmed tumours harboring more than one subtype $[8,9]$.

The implication of RTKs in the development, recurrence and treatment resistance of GBM [10] has led to small molecule tyrosine kinase inhibitors (TKIs) emerging as new treatment options. We assessed 12 TKIs inhibiting various kinases associated with the development and progression of GBM. Dasatinib and crizotinib were the most potent and reduced cell viability in a panel of GBM cell lines. Dasatinib is a broad spectrum inhibitor of SRC family kinases such as the non-receptor tyrosine kinases SRC, Fyn and Lyn [11]. SRC is frequently constitutively activated in GBM cell lines and patient tumors [12] and contributes to the invasive potential of GBM in vivo [13]. Crizotinib inhibits the Met, ROS1 
and anaplastic lymphoma kinase (ALK) RTKs. Met is expressed in all GBM cell lines [14], up to $72 \%$ of primary GBM tumors [15], promotes hypoxia driven invasion and the development of the pseudopalisades that are characteristic of GBM [16-18]. Furthermore, Met is also associated with the aquired resistance to cetuximab, a monoclonal antibody targeting EGFR [19]. ALK is poorly characterised in GBM but a number of reports suggest a role in the increased proliferation of GBM cells [20, 21].

In the current study, we demonstrate that a combination of dasatinib and crizotinib suppressed the viability of four established and two primary GBM cell lines. The combination also reduced the viability of GBM tumour spheroids. Moreover, our data indicates that the combination suppressed the activity and expression of Met, SRC and their downstream effectors. The combination synergistically increased apoptosis and abolished migration and invasion of the GBM cells and prevent neo-angiogenesis. Together, our results support the efficacy of the combination of two TKIs, dasatinib and crizotinib, for the treatment of GBM by targeting different oncogenic signaling pathways.

\section{RESULTS}

\section{TKIs reduce GBM cell viability in vitro}

We assessed the effect of several TKIs including sorafenib, nilotinib, sunitinib, imatinib, gefitinib, lapatinib, PD-173074, selumetinib, tofacitinib, pazopanib, dasatinib and crizotinib on the cellular viability of four established GBM cell lines (Table 1). The tyrosine kinases targeted were demonstrated to have an increased activity and/or expression in GBM and contribute to the progression, recurrence and treatment resistance of these tumors. The combination of dasatinib and crizotinib was the most cytotoxic across all the cell lines. We optimized the concentrations for both drugs to obtain a potent effect across all etablished and primary GBM cell lines used in this study and proceeded with $0.2 \mu \mathrm{M}$ of dasatinib and $4 \mu \mathrm{M}$ of crizotinib. Dasatinib and crizotinib treatment reduced the number of cells between 35 to $52 \%$ and 45 to $75 \%$, respectively, across all cell lines over a $72 \mathrm{~h}$ period (Figure 1). Combination of crizotinib and dasatinib was more cytotoxic compared to the single treatments and decreased the number of cells by 71 to $90 \%$ (Figure 1A).

\section{Cytotoxicity of the combination using GBM tumor spheroid models}

The established GBM cell line U87 and the primary GBM cell line NZG1003 both form stable tumor spheroids, a three-dimensional culture that mimics some aspects of the in vivo tumor organization and often better recapitulates the response of the tumor to the drug. The spheroids were grown for 4 days and photographed before being treated with dasatinib, crizotinib or combination for 4 days (Figure $1 \mathrm{~B}$ and 1C). At the end of the treatment period, spheroids were photographed and viability of the cells measured via an acid phosphatase activity assay (Figure 1DI-II). The combination was consistently more cytotoxic than the single treatments and decreased the viability of the tumor spheroids by nearly 70\%. Furthermore, using the U87 spheroids, we measured the effect of treatment on cell proliferation using an antibody directed against Ki67, a cellular marker of proliferation (Figure 1BIII). The control spheroid exhibited an intense Ki67 staining on the surface of the spheroid. Treatment with dasatinib reduces Ki67 expression but has no effect on the spheroid size despite a reduction of the cell number by nearly $20 \%$ (Figure 1DI). The treatment with crizotinib decreases cell proliferation while the combination limited Ki67 expression to a small number of cells at the periphery of the tumor spheroid (Figure 1BIII).

\section{Cell signaling in response to treatment}

We then tested the effect of the combination treatment on the expression of proteins associated with cell proliferation, survival and invasion. The combination decreased EGFR expression in LN-18, A172 and NZG1003 cells while abolishing it in U87, U373 and NZG0906 cells. Furthermore, the combination abolishes the expression of focal adhesion kinase (FAK), a protein involved in the migration and invasion of cancer cells. Dasatinib was also highly effective in the suppression of FAK while crizotinib treatment slightly reduced its expression only in the two primary cell lines. The phosphorylation of Met, the RTK targeted by crizotinib, was significantly decreased by dasatinib treatment in U87, LN-18, U373 and NZG1003 cells, but not in A172 or NZG0906 cells while crizotinib increased Met expression in all cell lines. We then considered the effect of combination treatment on the downstream effectors of these kinases. In our study, the phosphorylation of SRC is abolished in all cell lines while the expression of total SRC is not consistently altered following dasatinib treatment (Figure 2). Treatment with crizotinib did not affect the expression of SRC but reduced its phosphorylation. The combination completely suppressed SRC phosphorylation in all cell lines (Figure 2). AKT is a key signal transduction pathway found to be constitutively active in multiple GBM cell lines and tumors. The combination completely abolishes AKT phosphorylation in all cell lines but total AKT expression was only abolished in combination treated NZG0906 cells. We also evaluated the effect of treatment on cyclin D1 (CD1) expression. Dasatinib is a potent cytostatic agent and reduced CD1 expression in all cell lines but U87 while crizotinib increased CD1 
Table 1: The efficacy of TKIs against a panel of GBM cell lines

\begin{tabular}{|c|c|c|c|c|c|}
\hline \multirow[t]{2}{*}{ Drug } & \multirow[t]{2}{*}{ Targets } & \multicolumn{4}{|c|}{$\mathrm{IC}_{50}(\mu \mathrm{M})$} \\
\hline & & U87 & LN-18 & U373 & A172 \\
\hline Sorafenib & $\begin{array}{l}\text { VEGFR-2 } \\
\text { VEGFR-3 } \\
\text { KIT } \\
\text { PDGFR- } \beta\end{array}$ & 7.3 & 4.9 & 8.0 & 6.2 \\
\hline Nilotinib & $\begin{array}{c}\text { ABL1-2 } \\
\text { PDGFR } \\
\text { KIT } \\
\text { BCR-ABL }\end{array}$ & 12.5 & 14.9 & $>15$ & 10.2 \\
\hline Sunitinib & $\begin{array}{c}\text { VEGFR-1-2 } \\
\text { VEGFR-3 } \\
\text { KIT } \\
\text { PDGFR }\end{array}$ & 6.0 & 5.5 & $>15$ & 12.0 \\
\hline Imatinib & $\begin{array}{c}\text { ABL1-2 } \\
\text { PDGFR } \\
\text { KIT }\end{array}$ & $>15$ & $>15$ & $>15$ & $>15$ \\
\hline Gefitinib & EGFR & $>15$ & 12.2 & $>15$ & $>15$ \\
\hline Lapatinib & $\begin{array}{c}\text { EGFR } \\
\text { ERBB2 }\end{array}$ & 12.5 & 7.0 & 12.6 & 12.4 \\
\hline Dasatinib & $\begin{array}{c}\text { ABL1-2 } \\
\text { PDGFR } \\
\text { KIT } \\
\text { SRC } \\
\end{array}$ & 0.31 & 0.25 & 0.5 & 2.35 \\
\hline PD-173074 & FGFR-1 & 11.6 & 6.18 & 13.8 & 0.95 \\
\hline Selumetinib & MEK & 14.75 & $>15$ & 11.9 & $>15$ \\
\hline Crizotinib & $\begin{array}{l}\text { Met } \\
\text { ALK }\end{array}$ & 2.17 & 1.57 & 3.3 & 3.0 \\
\hline Tofacitinib & JAK3 & $>15$ & $>15$ & $>15$ & $>15$ \\
\hline Pazopanib & $\begin{array}{c}\text { VEGFR-1-2 } \\
\text { VEGFR-3 } \\
\text { PDGFR } \\
\text { KIT }\end{array}$ & $>15$ & $>15$ & $>15$ & $>15$ \\
\hline
\end{tabular}

expression in all cell lines but U87. The combination treatment heavily reduced the CD1 expression in all cell lines relative to crizotinib treatment. Finally, we demonstrated that the activation of the apoptotic effector caspase-3 was increased in all four cell lines following crizotinib treatment and more strongly with combination treatment (Figure 2).

\section{Subcellular localization of tyrosine kinases}

We examined the effect of the different treatments on the intracellular localization of SRC and Met in two established cell lines, LN-18 and U373 cells. In LN-18 cells, SRC is abundant at the periphery of the nucleus and shows strong accumulation in the lamellipodia. Treatment with dasatinib, crizotinib or combination abolishes perinuclear and lamellipodial SRC localization and disperses SRC within the cytoplasm (Figure 3A). In U373 cells, SRC expression in the nucleus is reduced by the treatment with crizotinib, dasatinib and combination (Figure 3B). Met localizes primarily on the plasma membrane but also in the perinuclear region in both cell lines while in LN-18 cells, Met co-localizes with SRC. Treatment with crizotinib or combination reduces the membrane and perinuclear localization of Met, resulting in a diffuse cytoplasmic staining. Dasatinib also decreases the perinuclear localization of Met in LN-18 and U373 


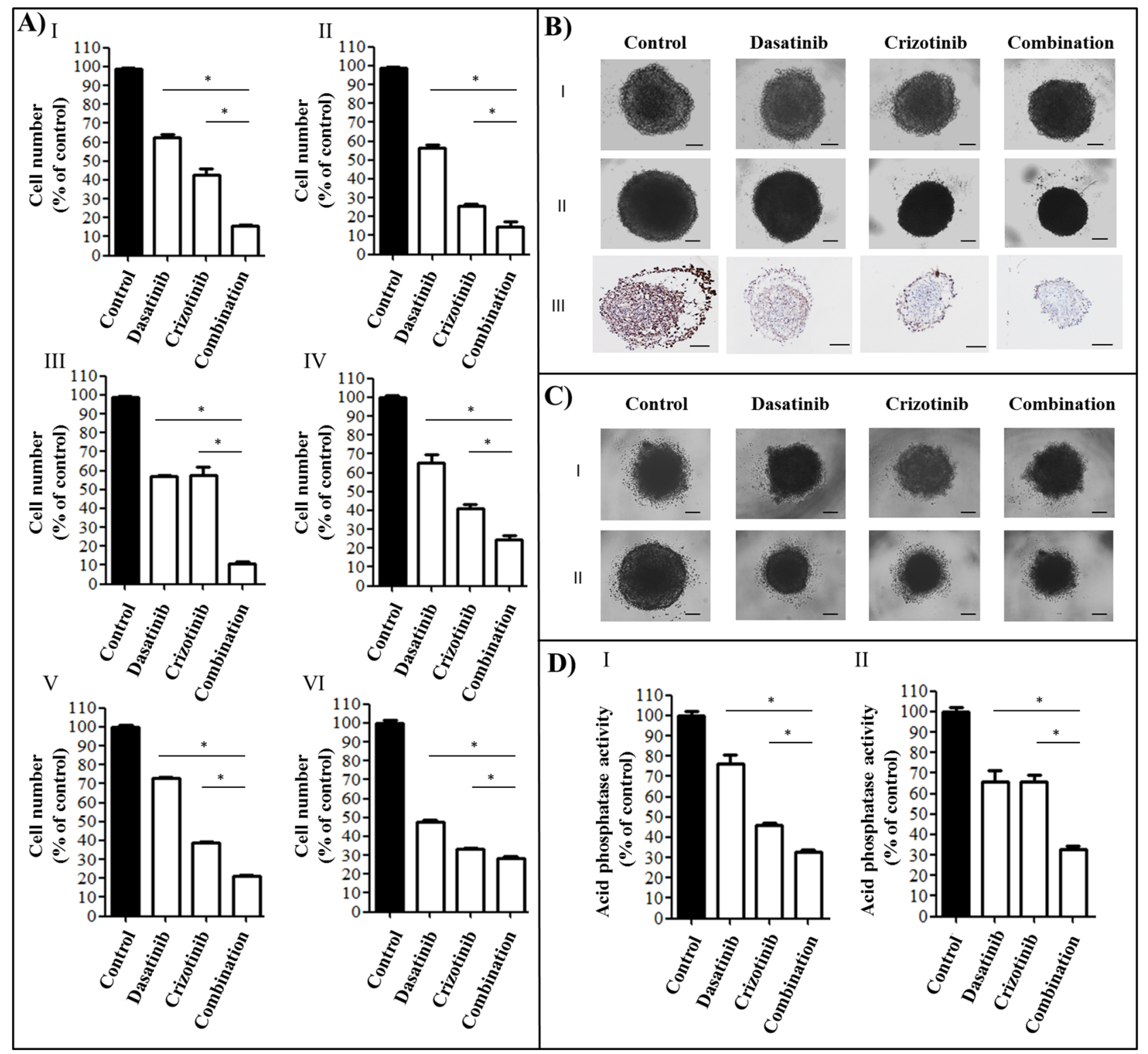

Figure 1: Cytotoxicity of a combination of dasatinib and crizotinib on GBM cell lines and GBM tumor spheroids. A. Cell number was measured following $72 \mathrm{~h}$ of treatment at concentrations of $0.2 \mu \mathrm{M}$ dasatinib and $4 \mu \mathrm{M}$ crizotinib using an SRB assay in I: U87, II: LN-18, III: U373, IV: A172, V: NZG1003 and VI: NZG0906 cells. Data are expressed as the mean \pm SEM. Experiments were conducted in triplicate and repeated independently three times. B. U87 spheroids I: before treatment, II: following 4 days treatment and III: Ki67 staining of spheroids treated for 4 days. Experiments were conducted in sextuplicate and repeated independently three times, representative images are shown. C. NZG1003 spheroids I: before treatment and II: following 4 days treatment. Experiments were conducted in sextuplicate and repeated independently three times, representative images are shown. D. Acid phosphatase assay of I: U87 and II: NZG1003 spheroids following 4 days of treatment. Data are expressed as the mean \pm SEM. Experiments were conducted in sextuplicate and repeated independently three times. Scale bars denote $100 \mu \mathrm{m}, *$ denotes $p \leq 0.05$ as determined by an ANOVA with a Bonferroni post-hoc test.

cells. Moreover, both treatments induce significant changes in the cellular morphology. SRC is known to influence the activity of multiple ion transporters [22] and treatment with dasatinib reduced the cell area by $50 \%$ in both cell lines. Met regulates cell cycle transition in the $\mathrm{G}_{1} / \mathrm{S}$ and $\mathrm{G}_{2} / \mathrm{M}$ phases of the cell cycle [23] and crizotinib treatment increased cell area by nearly 2.5 - and 1.3 -fold in LN-18 and U373 cells, respectively. In addition, crizotinib treatment promoted polynucleation in both cell lines. The combination treatment decreases the cell volume and polynucleation relative to crizotinib treatment. 


\begin{tabular}{|c|c|c|c|c|c|c|}
\hline Cell line & U87 & LN-18 & U373 & $\mathbf{A 1 7 2}$ & NZG1003 & NZG0906 \\
\hline Protein & 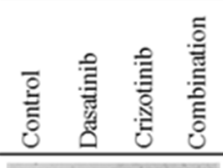 & 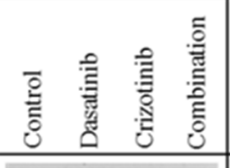 & 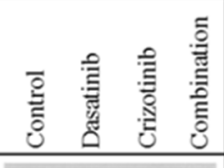 & 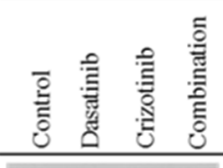 & 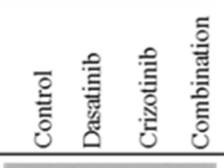 & 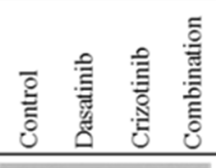 \\
\hline EGFR & $-\infty$ & 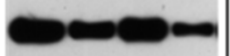 & 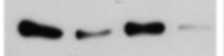 & $6-$ & & $-\cdots$ \\
\hline FAK & - & $-\quad-$ & $\bullet-$ & --6 & - & $=-$ \\
\hline Met & $=0-$ & $=--$ & $5=$ & $-5-$ & $--\infty$ & --- \\
\hline P-Met & - & - & -- & - & - & - \\
\hline $\mathrm{SRC}$ & - & $---\cdots$ & -0 & $-\infty-1$ & --- & $-6-$ \\
\hline P-SRC & -- & - & & $-\quad-$ & - & - \\
\hline AKT & $-\infty$ & $-\infty-$ & $-\infty-\infty$ & $-\infty$ & - & --- \\
\hline P-AKT & -5 & --- & $\rightarrow$ & - & $-\cdots$ & $-\cdots$ \\
\hline CD1 & --- & $-\frac{-}{-}-$ & $-\quad-$ & $--\infty$ & $\longrightarrow$ & $--\infty$ \\
\hline $\begin{array}{c}\text { Cleaved } \\
\text { Caspase-3 }\end{array}$ & $=0$ & $==$ & $-=0$ & $=$ & $=$ & \\
\hline$\beta$-tubulin & - & --- & besen & $-\infty$ & $-\infty-$ & --- \\
\hline
\end{tabular}

Figure 2: Combination of dasatinib and crizotinib decreases the activity and/or expression of Met, SRC and related proteins. GBM established and primary cell lines were treated with dasatinib $0.2 \mu \mathrm{M}$, crizotinib $4 \mu \mathrm{M}$ or their combination for $48 \mathrm{~h}$. Total lysates were analyzed by western blotting with antibodies as indicated.

\section{Mode of cell death induced by crizotinib, dasatinib and their combination}

We previously demonstrated by western blot that crizotinib and combination treatment resulted in the activation of caspase-3 (Figure 2). We further confirmed that the mode of cell death was via apoptosis using flow cytometry to measure early apoptotic events using annexin-V and PI staining as markers of the apoptotic and necrotic processes respectively. The concentration of dasatinib used in these experiments did not promote necrosis or apoptosis in any of the cell lines at any time point (Figure 4). The reduction in cell number observed with the SRB (Figure 1A), reduction in Ki67 staining of spheroids (Figure 1 BIII), lack of caspase-3 activation (Figure 2) and lack of apoptosis or necrosis induction (Figure 4) suggests that the mechanism of action of dasatinib is cytostatic. Conversely, crizotinib treatment induces apoptosis but not necrosis in all four established
GBM cell lines (Figure 4). Following combination treatment, a synergistic increase in apoptosis was observed after treatment for $72 \mathrm{~h}$ in all cell lines (Figure 4). For example, in LN-18 cells, the percentage of apoptotic cells is $1.3,33.9$ and $59.3 \%$ following dasatinib, crizotinib and combination treatments respectively.

To determine if the effects triggered by dasatinib and crizotinib are transient or associated with prolonged changes, we removed the drug containing media, replaced it with fresh growth media and measured the apoptosis over the subsequent $72 \mathrm{~h}$. The maintenance of apoptosis was heavily influenced by the cell line (Figure 4). In U87 cells, the number of apoptotic cells following combination treatment decreased rapidly to $8.4 \% 24 \mathrm{~h}$ after washout relative to $58.5 \%$ following $72 \mathrm{~h}$ of treatment. Importantly, the synergistic effect observed by the combination was lost and the apoptosis was comparable to the crizotinib treatment. Conversely, in LN-18, U373 and A172 cells, the synergistic increase of apoptosis triggered by the 


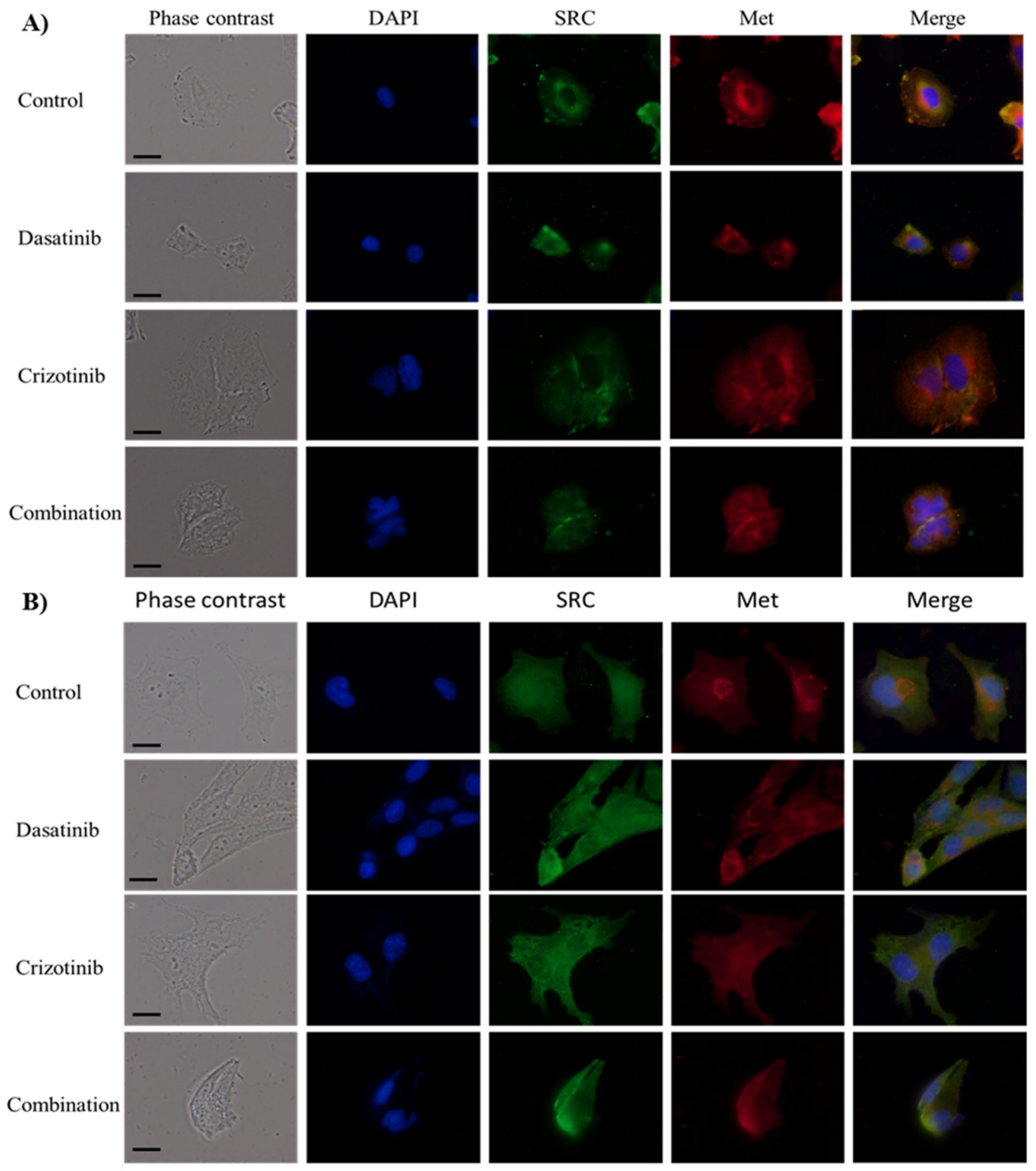

Figure 3: Immunocytochemistry of SRC and Met localization. Cellular localization of SRC and Met following treatment for $48 \mathrm{~h}$ with dasatinib, crizotinib or combination in A. LN-18 and B. U373 cells. Scale bar denotes $10 \mu \mathrm{m}$. Nuclei were visualized by DAPI while SRC and Met were labeled with a fluorescein and Texas-red conjugated secondary antibodies, respectively.

combination treatment was sustained over the $72 \mathrm{~h}$. These results further emphasize the relevance of the combination relative to single-agent treatment by prolonging the apoptotic effect in most cell lines and permanently altering the ability of the cells to recover from treatment in susceptible GBM cell lines.

\section{Cell cycle}

As shown previously, crizotinib treatment triggered polynucleation (Figure 3) while dasatinib treatment was sufficient to reduce cell number without inducing cell death (Figure 1, Figure 2 and Figure 4), suggesting that 

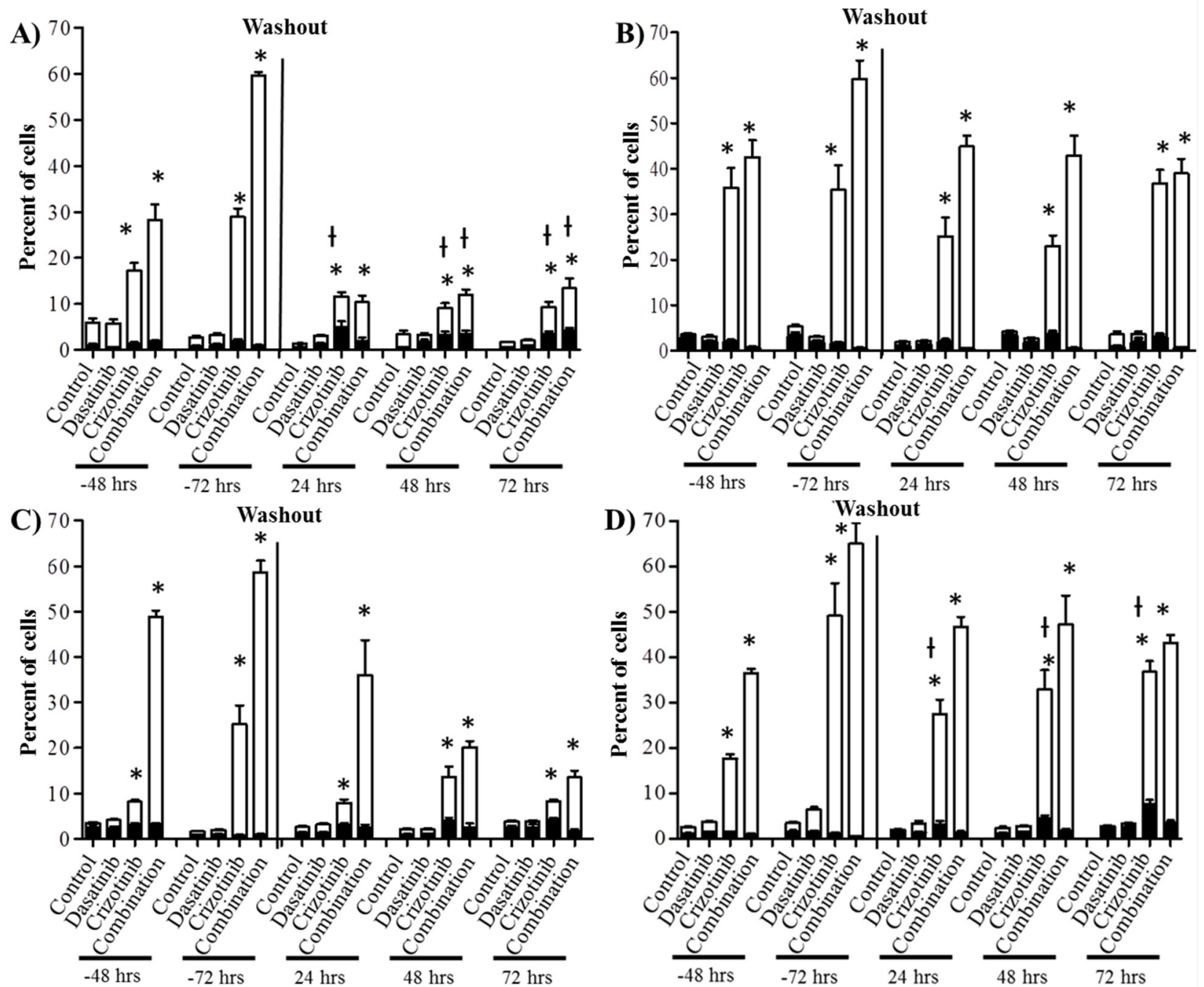

Figure 4: Combination treatment promotes apoptosis in GBM cell lines. Cells were treated with dasatinib $0.2 \mu \mathrm{M}$, crizotinib 4 $\mu \mathrm{M}$ or their combination for up to $72 \mathrm{~h}$ followed by a washout period of up to $72 \mathrm{~h}$, cell death was assessed at 48 and $72 \mathrm{~h}$ and every $24 \mathrm{~h}$ during the washout period. Bars denote necrotic; - (PI stained) and apoptotic; $\square$ (Annexin V stained). A. U87, B. LN-18, C. U373, and D. A172 cells. Experiments were conducted in triplicate and independently repeated three times, $p \leq 0.05$ relative to control for annexin V (*) and PI (1).

both drugs are able to alter DNA synthesis and cell cycle progression. Cell cycle analysis showed that dasatinib treatment transiently promotes accumulation of the cells in G1 phase of the cell cycle (1X DNA content) in all cell lines after $48 \mathrm{~h}$ treatment (Figure 5). Following treatment with crizotinib for 48 and $72 \mathrm{~h}$, a significant number of cells accumulated in the $\mathrm{G}_{2} / \mathrm{M}$ phase (2X DNA content) of the cell cycle $(p \leq 0.01)$ (Supplementary Tables S1-S4). However, even though this cell population failed to complete mitosis, they were able to re-enter the cell cycle and cause the formation of tetraploid (4X DNA content) and octoploid (8X DNA content) cells. The effect of crizotinib on $\mathrm{G}_{2} / \mathrm{M}$ accumulation and polyploidy were consistent after 48 and $72 \mathrm{~h}$ incubation but differs in intensity across all cell lines. LN-18 and U373 showed a rapid increase of tetraploid (4X DNA content) and octoploid (8X DNA content) cell populations while U87 and A172 are mainly characterized by $\mathrm{G}_{2} / \mathrm{M}$ arrest (Figure 5). The combination treatment also increased the quantity of the polyploid cell population relative to control cells but significantly reduces the proportion of tetraploid and octoploid cells relative to crizotinib treatment. For example, in LN-18 cells, the number of tetraploid and octoploid cells following crizotinib treatment was 39.3 and $15.6 \%$ while the in the combination the number were reduced to 12.7 and $1.2 \%$, respectively. Following washout, the polyploid cell population induced by crizotinib treatment is maintained while, in combination treated cells, the number of tetraploid and octoploid cells increased over the washout period. The presentation of 

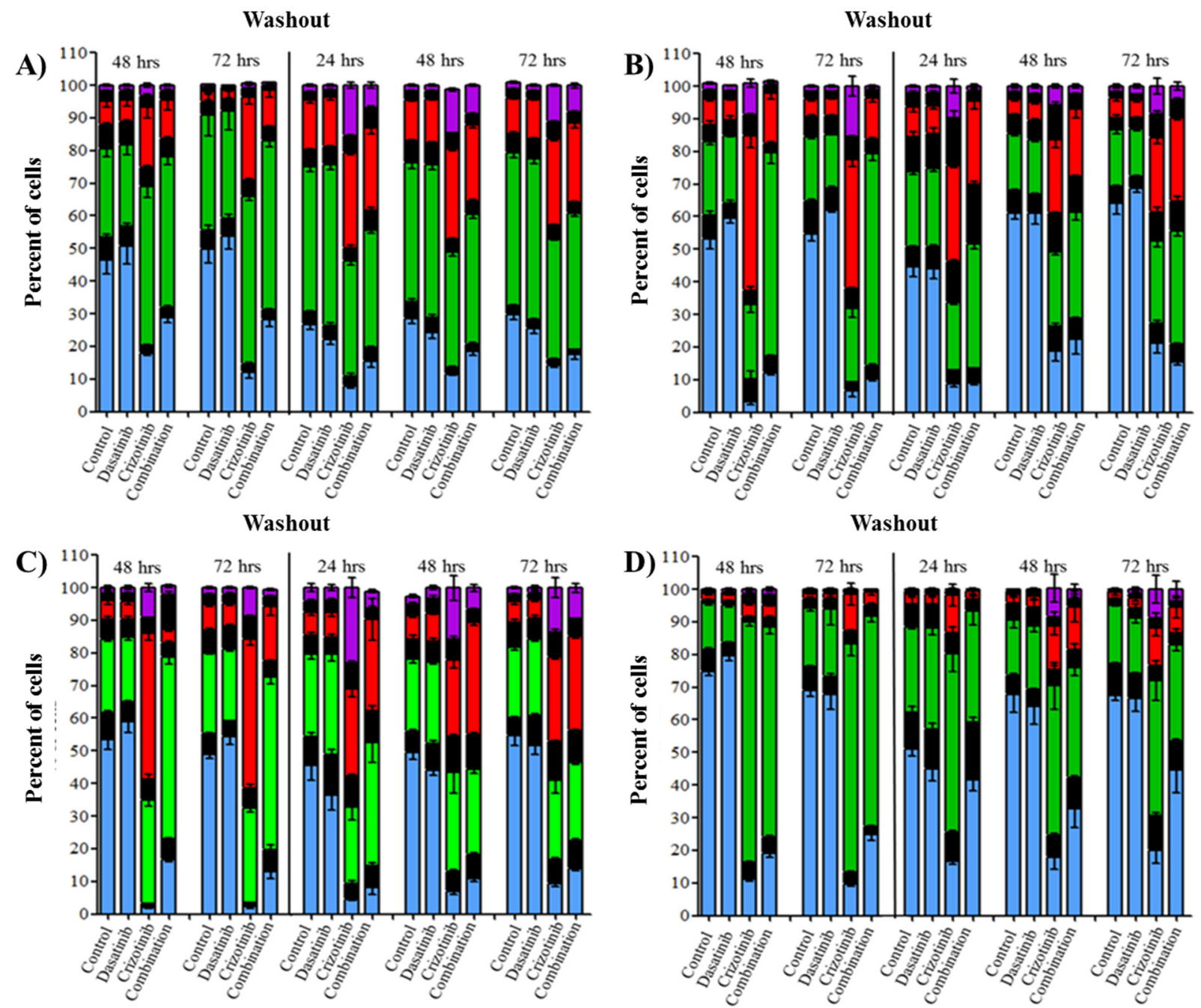

Figure 5: Combination treatment triggered cell cycle arrest in G2/M phase and increased occurrence of polyploid cells. Cells were treated with dasatinib $0.2 \mu \mathrm{M}$, crizotinib $4 \mu \mathrm{M}$ or their combination for up to $72 \mathrm{~h}$ followed by a washout period of up to $72 \mathrm{~h}$, cell cycle was assessed at 48 and $72 \mathrm{~h}$ and every $24 \mathrm{~h}$ during the washout period. Bars denote cells with 1X DNA $\sqsubset, 2 X$ DNA $\square, 4 X$

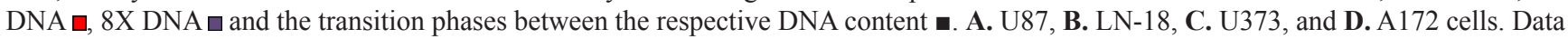
are expressed as the mean \pm SEM, experiments were conducted in triplicate and repeated independently three times. Statistical analysis is available in Supplementary Table S1-S4.

polyploid cells (Figure 5) does not closely correlate with apoptosis (Figure 4) demonstrating that dysregulation of mitosis is not the determining factor for the induction of apoptotic cell death.

\section{Crizotinib treatment disrupts correct mitotic spindle formation}

We previously observed that following crizotinib or combination treatment, a number of cells had more than one nucleus (Figure 3) and had up to 8-fold the normal DNA content (Figure 5). Polynucleation and polyploidy is often a consequence of dysfunctional formation of the mitotic apparatus. The mitotic spindles are involved in the segregation of chromatids and are the result of the interaction of a myriad of proteins dictating the dynamics of microtubule nucleation through polymerization of $\alpha$ and $\beta$ tubulin dimers. As shown in Figure 6, control and dasatinib treated cells exhibit normal mitotic spindle structures. Contrarily, treatment with crizotinib and combination for $48 \mathrm{~h}$ severely disrupts the formation of the mitotic spindle in LN-18 cells. This disruption is likely a consequence of the inhibition of aurora kinases by crizotinib and provides a plausible mechanism for the previously observed polynucleation (Figure 3 ) and polyploidy (Figure 5). 


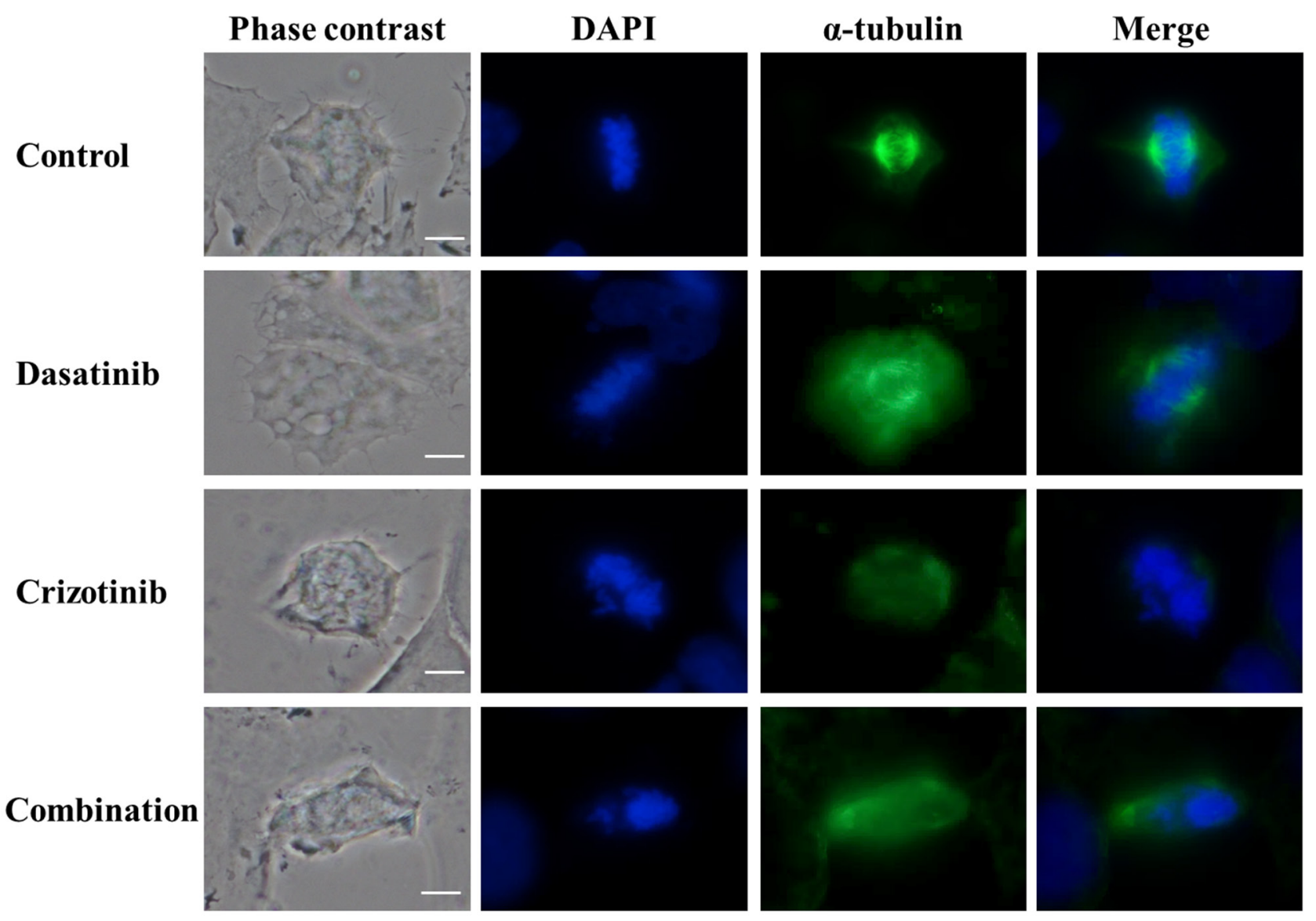

Figure 6: Combination of dasatinib and crizotinib impedes the formation of the $\alpha$-tubulin-labeled mitotic spindle. $L N-18$ cells were treated with dasatinib $0.2 \mu \mathrm{M}$, crizotinib $4 \mu \mathrm{M}$ or their combination for $48 \mathrm{~h}$. Mitotic spindle were visualized using $\alpha$-tubulin antibody conjugated to a fluorescein-labeled secondary antibody. Nuclei were stained by DAPI. The scale bar denotes $10 \mu \mathrm{m}$.

\section{The combination of crizotinib and dasatinib prevents migration, invasion, HUVEC tube formation and tube-like formation of GBM cells}

The capacity of GBM cells to invade the surrounding brain parenchyma is a serious impediment to the effective application of radiotherapy and chemotherapy. As seen in Figure 7A, migration of LN-18 cells is reduced following dasatinib and crizotinib treatment and abolished by combination treatment, at concentrations of $0.2 \mu \mathrm{M}$ dasatinib and $0.75 \mu \mathrm{M}$ crizotinib, insufficient to promote cell death after $20 \mathrm{~h}$ incubation. Furthermore, when the ability of cells to invade through a basement membrane was assessed, this sub-cytotoxic dose was sufficient to reduce the invasion of LN-18 cells by $80 \%$ following combination treatment (Figure 7B).

In vitro models of angiogenesis, using HUVEC cells, and vascular mimicry, using tumor cells, have been employed to ascertain if the current drug combination shows potential efficacy. As can be seen in Figure 8, the tube-like formation of HUVEC is inhibited by treatment with dasatinib while treatment with crizotinib has a moderate effect. Following combination treatment there is no apparent tube-like formation of HUVEC cells. When U87, U373, and A172 cells are seeded onto the Geltrex basement membrane, they also form long projections resembling that of the HUVEC cells, termed vascular mimicry. In these cells combination treatment completely abolishes the formation of the tube-like projections in both U87 and U373 cells and greatly reduces tube-like formation in A172 cells. LN-18 cells do not form these projections and so were not included in this experiment.

\section{DISCUSSION}

The development of alternative and effective ways to treat and reduce the recurrence of GBM is being actively explored. The Cancer Genome Atlas has identified the amplification of several RTKs such as EGFR, ERBB2, PDGFR $\alpha$, Kit, vascular endothelial growth factor 2 (VEGFR-2), fibroblast growth factor receptor 2, insulin receptor substrate 2 and Met [24-26]. Tyrosine kinase inhibitors have emerged as effective cancer therapeutics in many types of cancers and are being assessed for the treatment of GBM. Currently, 139 clinical trials in phase I or II using 27 different TKIs targeting various receptor 
A)

Control

Dasatinib

$(0.2 \mu \mathrm{M})$

Crizotinib

$(0.75 \mu \mathrm{M})$
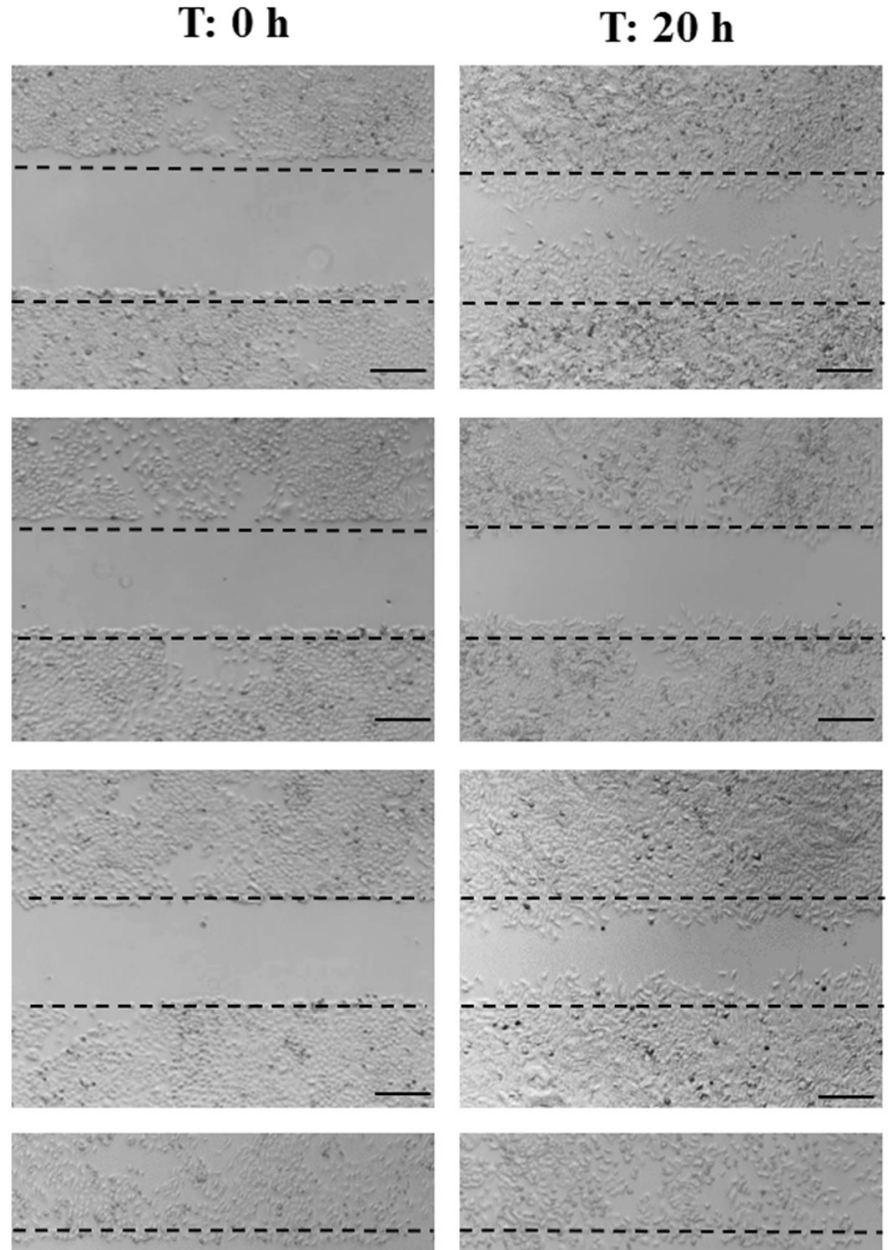

Combination
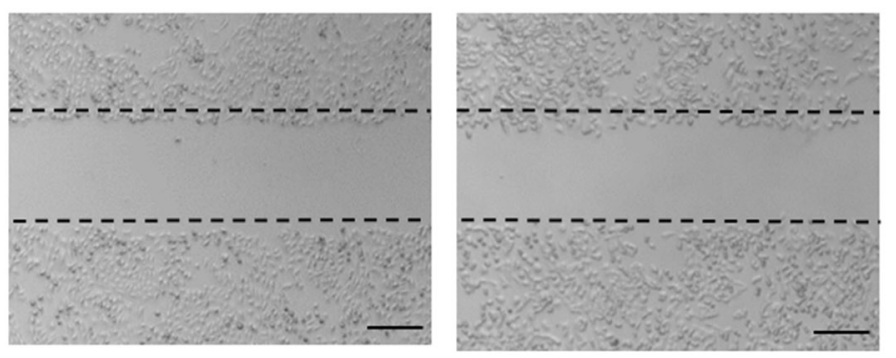

B)

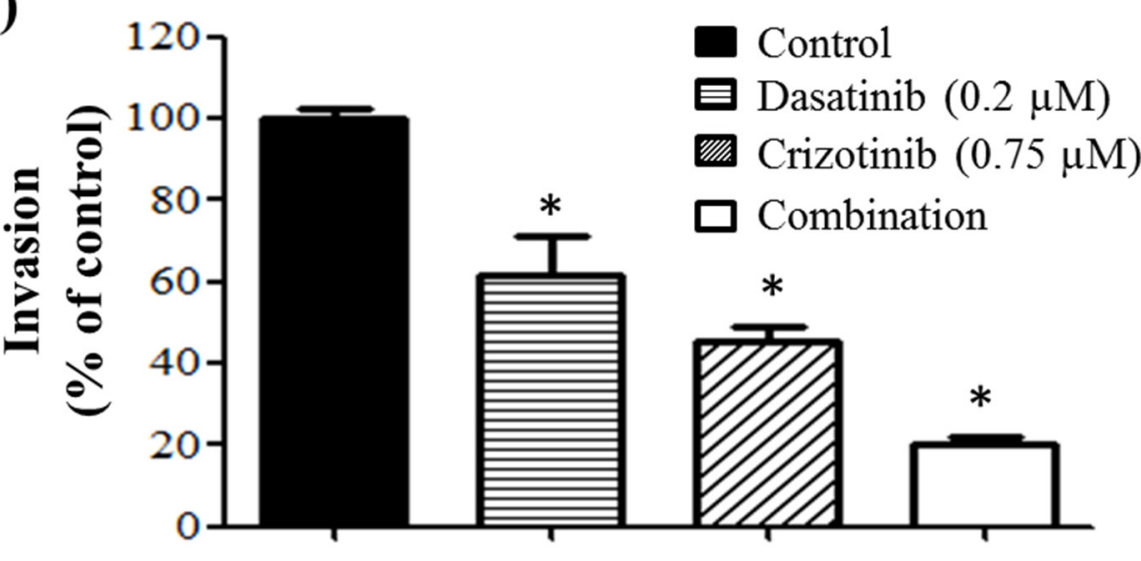

Figure 7: Migration and invasion of GBM cell lines. A. Migration of LN-18 cells following $20 \mathrm{~h}$ incubation and treatment with dasatinib $(0.2 \mu \mathrm{M})$ and/or crizotinib $(0.75 \mu \mathrm{M})$. The experiments were conducted in triplicate and repeated independently three times, representative pictures are shown. The scale bar denotes $200 \mu \mathrm{m}$. B. Invasion of LN-18 cells through a Geltrex basement membrane following $24 \mathrm{~h}$ of incubation and treatment with dasatinib $(0.2 \mu \mathrm{M})$ and/or crizotinib $(0.75 \mu \mathrm{M})$. The experiments were conducted in triplicate and repeated independently three times, ${ }^{*}$ denotes $p \leq 0.05$ relative to control. 

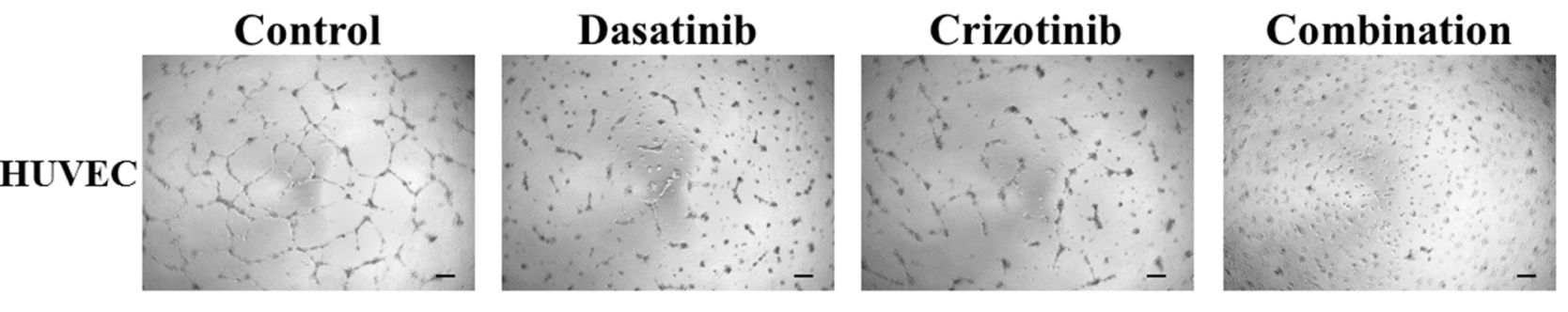

U87
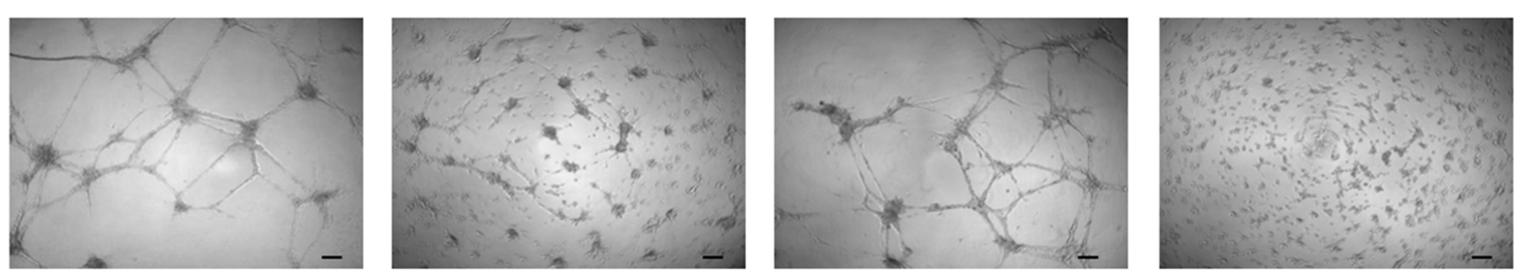

U373
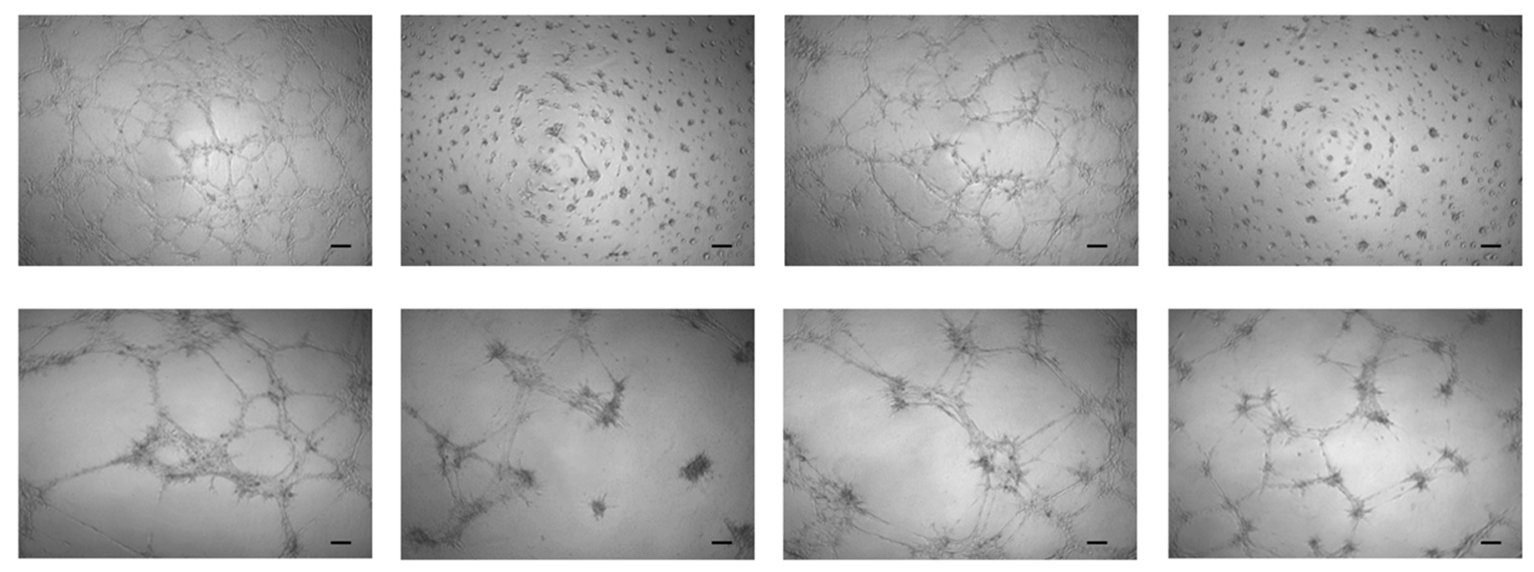

Figure 8: Tube formation of HUVEC cells and tube-like formation of U87, U373 and A172 cells. Cells were seeded onto Geltrex matrix and treated for $20 \mathrm{~h}$ before representative were pictures taken. The scale bar denotes $100 \mu \mathrm{m}$.

and non-receptor tyrosine kinases are active worldwide for the treatment of GBM. Although many molecular targets have already been identified, the efficacy of a specific TKI remains questionable due to the multiplicity, redundancy and heterogeneity of GBM signaling pathways which change during the course of the development of the tumor [27] and in response to treatment [28]. Furthermore, a subset of patients may have tumors with characteristics of more than one subtype [8]. Thus it is conceivable that the use of a combination of drugs would provide a better therapeutic outcome.

The present study described the response of four established and two primary GBM cell lines to a combination of the TKIs, crizotinib and dasatinib. Dasatinib inhibits multiple tyrosine kinases which are reported to be overexpressed or constitutively active in GBM such as the SRC family kinases, Kit, macrophage colony-stimulating factor receptor, PDGFR- $\alpha$ and $-\beta$, EphB1, EpHB2 and EphB4 [29-32]. The crossexamination of the broadly selective TKIs assessed in our study (Table 1) identified SRC as a protein of interest. SRC plays a key role in the signal transduction of a diverse panel of cell surface receptors such as Met,
PDGFR, EGFR and EGFRvIII, expressed in $25-64 \%$ of GBM patients [33-38]. SRC is involved in the regulation of a variety of cellular processes including cell volume regulation, cell proliferation and invasion. In the cell lines considered in this study, SRC was constitutively active which has also been observed in patient tumor samples [12]. The other TKI used in the combination treatment, crizotinib, inhibits multiple tyrosine kinases including Met, RON and ALK [39]. In this study, we considered only the effect of treatment on Met expression due to the paucity of understanding of the contribution of ALK and ROS1 to GBM. Western blots confirmed that the signaling of both SRC and Met was suppressed by single and combination treatment while the activity of the proliferative and survival downstream effector AKT was effectively suppressed by the combination treatment in both established and primary cell lines. Furthermore, the combination treatment was sufficient to reduce the expression of tyrosine kinases known to be overexpressed and to contribute to the progression and invasion of GBM such as EGFR and FAK [40, 41].

Dasatinib has proven to be well tolerated in clinical trials, but failed to improve overall survival 
either as a monotherapy or when combined to erlotinib [42], lomustine [43] or bevacizumab [44] for recurrent GBM. The limited efficacy of dasatinib was attributed to poor accumulation in the brain due to the activity of ATP-binding cassette transporters such as P-glycoprotein (P-gp) and breast cancer resistance protein which are highly expressed on the blood-brain barrier (BBB) and glioblastoma cells $[45,46]$. Our data and the data from previous studies [47] suggests that the limited efficacy may also be a consequence of the action of dasatinib being cytostatic as opposed to cytotoxic. This effect was highlighted by the absence of apoptosis and necrosis markers following treatment and the increase in G1 phase seen following 48 and $72 \mathrm{~h}$ dasatinib treatment (Figure 4).

No clinical trials examining the efficacy of crizotinib in GBM patients have been completed to date. Although, there have been several clinical trials initiated to test inhibitors of Met using small molecule inhibitors such as crizotinib (NCT02270034) and cabozantinib (NCT00704288) or antibodies directed against Met (NCT01632228). Crizotinib exhibits poor $\mathrm{BBB}$ penetration [48]; however, the $\mathrm{BBB}$ is often severely disrupted in the region of a tumor lesion and the pathological changes of the tumor vasculature increase permeability to small molecules [49]. Crizotinib is also a potent inhibitor of P-gp transport [41], it is possible that crizotinib treatment may prolonged the efficacy of a combination with dasatinib by reducing their efflux from the tumor tissue. Promisingly, combination treatment is sufficient to promote apoptotic cell death which was maintained for up to 72 hours following the removal of the drugs. This is an encouraging observation as it lowers the possibility of resistance emerging as the cells are committed to cell death.

The combination of dasatinib and crizotinib was shown to increase apoptosis but also to significantly reduce the proliferation of GBM cells. The promotion of cell cycle arrest in the $\mathrm{G}_{2} / \mathrm{M}$ phase of the cell cycle and the formation of polyploid cells by combination treatment was confirmed by western blot, FACS and immunocytochemistry analysis. Perturbations of the cell cycle were associated with a reduction of CD1 expression across all the cell lines. CD1 expression is generally associated with the transition from $\mathrm{G}_{1} / \mathrm{S}$ and $\mathrm{S} / \mathrm{G}_{2}$, however in cancer cells, its expression is high throughout the $\mathrm{S}$ and $\mathrm{G}_{2} / \mathrm{M}$ phases, promoting the constitutive phosphorylation of the retinoblastoma protein $[50,51]$. CD1 expression is regulated by SRC (Figure 2) and downregulation of SRC activity is sufficient to decrease CD1 expression and subsequently cell proliferation [52]. CD1 upregulation, however, was observed in crizotinib treated cells (Figure 2 ) and is associated with an increased proportion of polyploid cells [53], also observed following crizotinib treatment (Figure 5).
Cell cycle arrest in $\mathrm{G}_{2} / \mathrm{M}$ phase is usually sufficient to trigger apoptosis; in our study, the increased proportion of cells in the $\mathrm{G}_{2} / \mathrm{M}$ phase observed in the combination treatment is associated with a larger quantity of apoptotic cells. The $\mathrm{G}_{2} / \mathrm{M}$ phase accumulation can be the result of the formation of aberrant mitotic spindles observed following crizotinib and combination treatments (Figure 6) which is usually associated with the impaired segregation of chromosomes, $\mathrm{G}_{2} / \mathrm{M}$ arrest and increased apoptosis [54].

We also observed an increased number of polyploid (4X and 8X DNA) cells following crizotinib treatment which seems to be associated with a decreased number of apoptotic cells. Studies have suggested that polyploidy is associated with apoptosis resistance [55]. While the combination treatment also increased the proportion of polyploid cells relative to control the proportion of polyploid cells relative to crizotinib treatment was decreased. This combination may reduce treatment resistance by avoiding the genetic instability induced by crizotinib monotherapy.

Moreover, our results showed that the combination treatment decreased migration and reduced cellular invasion, both essential to metastases. The anti-invasive potential of the combination of dasatinib and crizotinib occurs at low crizotinib concentration. This effect is a particularly important observation as invasion into the surrounding healthy brain ultimately reduces the efficacy of all standard treatments for GBM. Traditional chemotherapies are often ineffective against invading cells as these cells suppress their proliferation, reducing the damage caused by agents that promote DNA damage [56]. Moreover, GBM lesions are highly vascularized [57] but antiangiogenic therapies show poor efficacy in GBM [58]. Our results show that the combination of dasatinib and crizotinib decreases angiogenesis and vascular mimicry in an in vitro model. The combination of the anti-angiogenic and anti-invasive properties is an essential consideration as the clinical usefulness of Bevacizumab, an antiangiogenic therapy, has been limited by the promotion of the invasive phenotype [59].

In conclusion, our results demonstrated that a combination of dasatinib and crizotinib was sufficient to promote apoptosis, reduce cell migration and invasion and abolish neo-angiogenesis. The combination was sufficient to reduce the activity of signaling pathways essential for GBM survival and treatment resistance. These findings suggest that the combination approach has therapeutic potential, and further studies are warranted to test its efficacy in vivo.

\section{MATERIALS AND METHODS}

\section{Materials}

Sorafenib, nilotinib, sunitinib, imatinib, gefitinib, lapatinib, dasatinib, PD-173074, selumetinib, 
crizotinib, tofacitinib and pazopanib were purchased from LC Laboratories (Woburn, Massachusetts, USA). Roswell Park Memorial Institute Medium (RPMI) and Geltrex basement membrane was purchased from Life Technologies (North Shore City, New Zealand). Met, P-Met (Y1234/Y1235), SRC, P-SRC (Y416), AKT, P-ATK (S473), cyclin D1, cleaved caspase 3, $\alpha$-tubulin and EGFR antibodies were purchased from Cell Signaling Technology (Danvers, Massachusetts, USA). $\beta$-Tubulin was purchased from Sigma-Aldrich (Auckland, New Zealand).

\section{Cell culture}

A172 and LN-18 cells were purchased from the American Type Culture Collection. U373 cells were generously provided by Dr. Andrew Bahn (University of Otago, New Zealand). Cells were cultured in RPMI medium supplemented with $5 \%$ fetal bovine serum (FBS) and maintained in a humidified atmosphere at $37^{\circ} \mathrm{C}, 5 \% \mathrm{CO}_{2}$. Spheroids were grown in 96 well plates with a non-adherent base of $50 \mu \mathrm{L} 1.5 \%$ agarose. Primary GBM cells (NZG0906 and NZG1003) were isolated and cultured from GBM material obtained from patients undergoing debulking surgery as described previously [60].

\section{Cytotoxicity}

Cells were seeded in 96-well plates (U87: 6,000, LN-18: 5,000, U373: 4,000, A172: 4,000 cells/well) and incubated for $24 \mathrm{~h}$. The cells were then treated as indicated in each experiment and incubated for a further $72 \mathrm{~h}$. The cytotoxicity was assessed using a sulforhodamine B (SRB) assay as described previously [61]. Viability of spheroids was assessed using the acid phosphatase assay. Spheroids were collected into tubes, centrifuged for 5 minutes at 1000 RPM and washed 3 times with cold phosphate buffered saline (PBS). The supernatant was aspirated and $100 \mu \mathrm{L}$ of cold PBS was placed on top and the spheroid sonicated. The solution was transferred to a 96 well plate and $100 \mu \mathrm{L}$ of $0.1 \mathrm{M}$ sodium acetate, $0.1 \%$ (vol/vol) Triton X-100 and $2 \mathrm{mg} / \mathrm{mL}$ para-Nitrophenylphosphate was added to each well. The solution was incubated at $37^{\circ} \mathrm{C}$ for 90 minutes before the reaction was halted using $10 \mu \mathrm{L}$ of $\mathrm{NaOH}$ and the absorbance read at $405 \mathrm{~nm}$ deducting background at $630 \mathrm{~nm}$. Acid phosphatase samples were conducted in sextuplicate and the experiment independently repeated 3 times.

\section{Proliferation}

Spheroids were collected after treatment for 4 days and frozen in Optimum Cutting Temperature from Newcomer supply (Middleton, WI, USA). The spheroids were sectioned at $10 \mu \mathrm{m}$ and incubated overnight with rabbit anti-Ki67 (Epitomics, Burlingame, CA, USA). Slides were incubated with biotinylated goat antirabbit (Dako, Campbellfield, Australia) and then with streptavidin (BD Pharmingen) before development with 3, 3'-diaminobenzidine tetrahydrochloride (DAB) (BD Pharmingen) and counterstaining with hematoxylin QS (Vector Laboratories).

\section{Mode of cell death}

Cells were seeded in 6 -well plates $(65,000$ cells/ well) and incubated for $24 \mathrm{~h}$. Cells were treated as indicated and incubated for 48 and $72 \mathrm{~h}$. For washout experiments, the media was aspirated, and the cells washed twice with PBS, before addition of fresh growth media. At the end of the treatment period, apoptosis was assessed using Annexin-V-FLUOS/propidium iodide (PI) staining, as described previously [62]. Samples were analyzed using a FACScalibur flow cytometer, and the proportion of apoptotic cells was determined using CellQuest Pro software (BD Biosciences, San Jose, CA, USA).

\section{Cell cycle}

Cells were seeded in a 6 -well plate $(65,000$ cells/ well) and incubated for $24 \mathrm{~h}$ before treatment. At the end of the treatment period, cell cycle distribution was assessed using PI staining, as previously described [62]. Cells were analyzed using a FACScalibur flow cytometer (BD Biosciences, San Jose, CA, USA) and the proportion of cells in each of $\mathrm{G}_{0} / \mathrm{G}_{1}{ }^{-}$, S- and $\mathrm{G}_{2} / \mathrm{M}$-phases were determined using CellQuest Pro software.

\section{Immunoblotting}

Cells were seeded in petri dishes (200,000 cells) and incubated for $24 \mathrm{~h}$ before being treated for $48 \mathrm{~h}$. Following the treatment period, the cells were washed with PBS and lysed in Tris- $\mathrm{HCl} 50 \mathrm{mM}$ (pH 8), sodium chloride $(\mathrm{NaCl})$ $150 \mathrm{mM}$, Triton X-100 1\%, sodium dodecyl sulfate (SDS) $1 \%$, sodium fluoride $(\mathrm{NaF}) 1 \mathrm{mM}$, sodium orthovanadate $200 \mu \mathrm{M}$, and protease inhibitors (leupeptin $1 \mu \mathrm{g} / \mathrm{mL}$, aprotinin $1 \mu \mathrm{g} / \mathrm{mL}$, phenylmethylsulfonyl fluoride (PMSF) $1 \mathrm{mM}$ ). The lysates were cleared from insoluble material by centrifugation at $12,000 \mathrm{rpm}$ for $10 \mathrm{~min}$, subjected to SDS-polyacrylamide gel electrophoresis, and analyzed by western blotting.

\section{Indirect immunofluorescence microscopy}

Cells were seeded onto a glass coverslip (20,000 cells/well) and incubated for $24 \mathrm{~h}$ before being treated for $48 \mathrm{~h}$. The cells were washed with PBS and fixed with $4 \%$ paraformaldehyde overnight at $4{ }^{\circ} \mathrm{C}$. The cells were washed with Tris-buffered saline (TBS) twice and 
permeabilized with TBS: Triton X-100 $0.2 \%$ for $5 \mathrm{~min}$, washed with TBS and blocked with $1.5 \%$ goat serum. Cells were incubated with $60 \mu \mathrm{L}$ of $50 \mu \mathrm{g} / \mathrm{mL}$ anti- $\alpha-$ tubulin, anti-Met or anti-SRC antibody overnight at $4^{\circ} \mathrm{C}$, washed with TBS before incubation a secondary FITC or Texas red-labeled antibodies for $1 \mathrm{~h}$ at room temperature. Cells were washed with TBS before being incubated in $50 \mu \mathrm{L}$ of $50 \mathrm{ng} / \mathrm{mL} 4^{\prime}, 6$-diamidino2-phenylindole (DAPI) in the dark for 30 minutes. Cells were washed with TBS and glass coverslips were mounted onto microscope slides using ProLong Gold antifade reagent.

\section{Migration}

LN-18 cells were seeded in 6-well plates $(100,000$ cells/well) and grown to $80 \%$ confluence. Scratches were made in the cell monolayer followed by extensive washing to remove cell debris. Then growth media was added to the cells and treatments were applied. Representative photographs were taken, and the cells were incubated for $20 \mathrm{~h}$ before photographs were taken again.

\section{Invasion}

LN-18 (20,000 cells) were seeded onto Geltrex (diluted in a $1: 1$ ratio with $\mathrm{RPMI}$ ) coated invasion membranes ( $8 \mu \mathrm{m}$ pore; BD Biosciences) with or without treatment for $20 \mathrm{~h}$. Lower chambers contained RPMI supplemented with chemoattractant, 5\% FBS. Cells from each well were counted under an inverted microscope at $200 \times$ magnification. Data were collected from three independent experiments, each done in triplicate.

\section{Tube formation assay}

Tube formation was carried out using human umbilical vein endothelial cells (HUVEC) as described by [62]. Briefly, HUVEC $\left(1.5 \times 10^{4}\right.$ cells/well $)$, U87 $(1.5 \times$ $10^{4}$ cells/well $), \mathrm{U} 373\left(1.4 \times 10^{4}\right.$ cells/well $)$ and A172 (1.4 $\times 10^{4}$ cells/well) were seeded on the top of Geltrex layer in 96-well plates. Cells were seeded, treated as specified and incubated for $20 \mathrm{~h}$ at $37^{\circ} \mathrm{C}$ in $5 \% \mathrm{CO} 2$ atmosphere. After the incubation time, pictures were taken at $20 \mathrm{x}$ magnification.

\section{Statistics}

Statistical analysis was carried out using GraphPad Prism $^{\mathrm{TM}}$. In order to correct for the correlation, covariance and non-normal distribution of the compositional cell cycle data, the data was subjected to Logit transformation and analyzed using a two-way ANOVA with a Bonferroni post hoc test. All other data was assessed via a one-way ANOVA with a Bonferroni post-hoc test. Significance was set at $p \leq 0.05$.

\section{ACKNOWLEDGMENTS AND FUNDING}

The authors would like to acknowledge Professor Rhonda Rosengren and Dr Sarah Baird for their assistance with the preparation of this manuscript.

This work has been supported by OSMS Strategic Research Fund (108749.01.S.LM) and University of Otago Research Grants UORG (109420.01.R.LM) to KG and ST.

\section{CONFLICTS OF INTEREST}

The authors declare no conflict of interest.

\section{REFERENCES}

1. Ostrom QT, Gittleman H, Liao P, Rouse C, Chen Y, Dowling J, Wolinsky Y, Kruchko C, Barnholtz-Sloan J. CBTRUS statistical report: primary brain and central nervous system tumors diagnosed in the United States in 20072011. Neuro-oncology. 2014; 16:iv1-63.

2. Nagarajan RP, Costello JF. Epigenetic mechanisms in glioblastoma multiforme. Seminars in Cancer Biology. 2009; 19:188-197.

3. Mitchell DA, Xie W, Schmittling R, Learn C, Friedman A, McLendon RE, Sampson JH. Sensitive detection of human cytomegalovirus in tumors and peripheral blood of patients diagnosed with glioblastoma. Neuro-oncology. 2008; 10:10-18.

4. Wrensch M, Bondy ML, Wiencke J, Yost M. Environmental risk factors for primary malignant brain tumors: a review. Journal of neuro-oncology. 1993; 17:47-64.

5. Ugonabo I, Bassily N, Beier A, Yeung JT, Hitchcock L, De Mattia F, Karim A. Familial glioblastoma: A case report of glioblastoma in two brothers and review of literature. Surgical neurology international. 2011; 2.

6. Stupp R, Hegi ME, Mason WP, van den Bent MJ, Taphoorn MJB, Janzer RC, Ludwin SK, Allgeier A, Fisher B, Belanger K, Hau P, Brandes AA, Gijtenbeek J, et al. Effects of radiotherapy with concomitant and adjuvant temozolomide versus radiotherapy alone on survival in glioblastoma in a randomised phase III study: 5-year analysis of the EORTC-NCIC trial. The Lancet Oncology. 2009; 10:459-466.

7. Verhaak RGW, Hoadley KA, Purdom E, Wang V, Qi Y, Wilkerson MD, Miller CR, Ding L, Golub T, Mesirov JP, Alexe G, Lawrence M, O'Kelly M, et al. Integrated Genomic Analysis Identifies Clinically Relevant Subtypes of Glioblastoma Characterized by Abnormalities in PDGFRA, IDH1, EGFR, and NF1. Cancer Cell. 2010; 17:98-110.

8. Szerlip NJ, Pedraza A, Chakravarty D, Azim M, McGuire J, Fang Y, Ozawa T, Holland EC, Huse JT, Jhanwar S, Leversha MA, Mikkelsen T, Brennan CW. Intratumoral heterogeneity of receptor tyrosine kinases EGFR and 
PDGFRA amplification in glioblastoma defines subpopulations with distinct growth factor response. Proceedings of the National Academy of Sciences. 2012; 109:3041-3046.

9. Snuderl M, Fazlollahi L, Le Long P, Nitta M, Zhelyazkova Boryana H, Davidson Christian J, Akhavanfard S, Cahill Daniel P, Aldape Kenneth D, Betensky Rebecca A, Louis David N, Iafrate AJ. Mosaic Amplification of Multiple Receptor Tyrosine Kinase Genes in Glioblastoma. Cancer Cell. 2011; 20:810-817.

10. Carrasco-Garcia E, Saceda M, Martinez-Lacaci I. Role of receptor tyrosine kinases and their ligands in glioblastoma. Cells. 2014; 3:199-235.

11. Vandyke K, Fitter S, Zannettino ACW. The tyrosine kinase inhibitor dasatinib (SPRYCEL) inhibits chondrocyte activity and proliferation. Blood Cancer Journal. 2011; 1:e2.

12. Du J, Bernasconi P, Clauser KR, Mani DR, Finn SP, Beroukhim R, Burns M, Julian B, Peng XP, Hieronymus H, Maglathlin RL, Lewis TA, Liau LM, et al. Bead-based profiling of tyrosine kinase phosphorylation identifies SRC as a potential target for glioblastoma therapy. Nature biotechnology. 2009; 27:77-83.

13. Ahluwalia MS, Groot Jd, Liu W, Gladson CL. Targeting SRC in glioblastoma tumors and brain metastases: Rationale and preclinical studies. Cancer Letters. 2010; 298:139-149.

14. Kong D-S, Song S-Y, Kim D-H, Joo KM, Yoo J-S, Koh JS, Dong SM, Suh Y-L, Lee J-I, Park K, Kim JH, Nam D-H. Prognostic significance of c-Met expression in glioblastomas. Cancer. 2009; 115:140-148.

15. Koochekpour S, Jeffers M, Rulong S, Taylor G, Klineberg E, Hudson EA, Resau JH, Vande Woude GF. Met and hepatocyte growth factor/scatter factor expression in human gliomas. Cancer research. 1997; 57:5391-5398.

16. Brat DJ, Castellano-Sanchez AA, Hunter SB, Pecot M, Cohen C, Hammond EH, Devi SN, Kaur B, Van Meir EG. Pseudopalisades in glioblastoma are hypoxic, express extracellular matrix proteases, and are formed by an actively migrating cell population. Cancer research. 2004; 64:920-927.

17. Eckerich C, Zapf S, Fillbrandt R, Loges S, Westphal M, Lamszus K. Hypoxia can induce c-Met expression in glioma cells and enhance SF/HGF-induced cell migration. International Journal of Cancer. 2007; 121:276-283.

18. Pennacchietti S, Michieli P, Galluzzo M, Mazzone M, Giordano S, Comoglio PM. Hypoxia promotes invasive growth by transcriptional activation of the met protooncogene. Cancer Cell. 2003; 3:347-361.

19. Wheeler DL, Huang S, Kruser TJ, Nechrebecki MM, Armstrong EA, Benavente S, Gondi V, Hsu KT, Harari PM. Mechanisms of acquired resistance to cetuximab: role of HER (ErbB) family members. Oncogene. 2008; 27:3944-3956.

20. Grzelinski M, Steinberg F, Martens T, Czubayko F, Lamszus K, Aigner A. Enhanced Antitumorigenic Effects in Glioblastoma on Double Targeting of Pleiotrophin and
Its Receptor ALK. Neoplasia (New York, NY). 2009; 11:145-156.

21. Powers C, Aigner A, Stoica GE, McDonnell K, Wellstein A. Pleiotrophin signaling through anaplastic lymphoma kinase is rate-limiting for glioblastoma growth. The Journal of biological chemistry. 2002; 277:14153-14158.

22. Cohen DM. SRC family kinases in cell volume regulation. American journal of physiology Cell physiology. 2005; 288:C483-493.

23. Factor VM, Seo D, Ishikawa T, Kaposi-Novak P, Marquardt JU, Andersen JB, Conner EA, Thorgeirsson SS. Loss of c-Met disrupts gene expression program required for $\mathrm{G} 2 / \mathrm{M}$ progression during liver regeneration in mice. PloS one. 2010; 5.

24. Joensuu H, Puputti M, Sihto H, Tynninen O, Nupponen NN. Amplification of genes encoding KIT, PDGFR $\alpha$ and VEGFR2 receptor tyrosine kinases is frequent in glioblastoma multiforme. The Journal of Pathology. 2005; 207:224-231.

25. Puputti M, Tynninen O, Sihto H, Blom T, Maenpaa H, Isola J, Paetau A, Joensuu H, Nupponen NN. Amplification of KIT, PDGFRA, VEGFR2, and EGFR in gliomas. Molecular cancer research : MCR. 2006; 4:927-934.

26. Wullich B, Muller HW, Fischer U, Zang KD, Meese E. Amplified met gene linked to double minutes in human glioblastoma. European journal of cancer (Oxford, England : 1990). 1993; 29A:1991-1995.

27. Patel AP, Tirosh I, Trombetta JJ, Shalek AK, Gillespie SM, Wakimoto H, Cahill DP, Nahed BV, Curry WT, Martuza RL, Louis DN, Rozenblatt-Rosen O, Suva ML, et al. Single-cell RNA-seq highlights intratumoral heterogeneity in primary glioblastoma. Science (New York, NY). 2014; 344:1396-1401.

28. Zhang RR, Pointer KB, Kuo JS, Dempsey RJ. Mutational analysis reveals the origin and therapy-driven evolution of recurrent glioma. Neurosurgery. 2014; 75:N9-10.

29. Melnick JS, Janes J, Kim S, Chang JY, Sipes DG, Gunderson D, Jarnes L, Matzen JT, Garcia ME, Hood TL, Beigi R, Xia G, Harig RA, et al. An efficient rapid system for profiling the cellular activities of molecular libraries. Proceedings of the National Academy of Sciences of the United States of America. 2006; 103:3153-3158.

30. Vandyke K, Dewar AL, Farrugia AN, Fitter S, Bik To L, Hughes TP, Zannettino ACW. Therapeutic concentrations of dasatinib inhibit in vitro osteoclastogenesis. Leukemia. 2008; 23:994-997.

31. Lombardo LJ, Lee FY, Chen P, Norris D, Barrish JC, Behnia K, Castaneda S, Cornelius LA, Das J, Doweyko AM, Fairchild C, Hunt JT, Inigo I, et al. Discovery of N-(2-chloro6-methyl- phenyl)-2-(6-(4-(2-hydroxyethyl)- piperazin1-yl)-2-methylpyrimidin-4-ylamino)thiazole-5-carboxamide (BMS-354825), a dual Src/Abl kinase inhibitor with potent antitumor activity in preclinical assays. Journal of medicinal chemistry. 2004; 47:6658-6661. 
32. Lassman AB, Pugh SL, Gilbert MR, Aldape KD, Geinoz S, Beumer JH, Christner SM, Komaki R, DeAngelis LM, Gaur R, Youssef E, Wagner H, Won M, et al. Phase 2 trial of dasatinib in target-selected patients with recurrent glioblastoma (RTOG 0627). Neuro-oncology. 2015.

33. Gan HK, Cvrljevic AN, Johns TG. The epidermal growth factor receptor variant III (EGFRvIII): where wild things are altered. The FEBS journal. 2013; 280:5350-5370.

34. Blake RA, Broome MA, Liu X, Wu J, Gishizky M, Sun L, Courtneidge SA. SU6656, a selective src family kinase inhibitor, used to probe growth factor signaling. Molecular and cellular biology. 2000; 20:9018-9027.

35. Twamley-Stein GM, Pepperkok R, Ansorge W, Courtneidge SA. The Src family tyrosine kinases are required for platelet-derived growth factor-mediated signal transduction in NIH 3 T3 cells. Proceedings of the National Academy of Sciences of the United States of America. 1993; 90:7696-7700.

36. Herynk MH, Zhang J, Parikh NU, Gallick GE. Activation of Src by c-Met overexpression mediates metastatic properties of colorectal carcinoma cells. Journal of experimental therapeutics \& oncology. 2007; 6:205-217.

37. Maa MC, Leu TH, McCarley DJ, Schatzman RC, Parsons SJ. Potentiation of epidermal growth factor receptor-mediated oncogenesis by c-Src: implications for the etiology of multiple human cancers. Proceedings of the National Academy of Sciences. 1995; 92:6981-6985.

38. Lu KV, Zhu S, Cvrljevic A, Huang TT, Sarkaria S, Ahkavan D, Dang J, Dinca EB, Plaisier SB, Oderberg I, Lee Y, Chen Z, Caldwell JS, et al. Fyn and SRC are effectors of oncogenic epidermal growth factor receptor signaling in glioblastoma patients. Cancer research. 2009; 69:6889-6898.

39. Ou S-HI. Crizotinib: a novel and first-in-class multitargeted tyrosine kinase inhibitor for the treatment of anaplastic lymphoma kinase rearranged non-small cell lung cancer and beyond. Drug Design, Development and Therapy. 2011; 5:471-485.

40. Zheng Q, Han L, Dong Y, Tian J, Huang W, Liu Z, Jia X, Jiang T, Zhang J, Li X, Kang C, Ren H. JAK2/STAT3 targeted therapy suppresses tumor invasion via disruption of the EGFRvIII/JAK2/STAT3 axis and associated focal adhesion in EGFRvIII-expressing glioblastoma. Neurooncology. 2014; 16:1229-1243.

41. Huang PH, Mukasa A, Bonavia R, Flynn RA, Brewer ZE, Cavenee WK, Furnari FB, White FM. Quantitative analysis of EGFRvIII cellular signaling networks reveals a combinatorial therapeutic strategy for glioblastoma. Proceedings of the National Academy of Sciences of the United States of America. 2007; 104:12867-12872.

42. Reardon D, Desjardins A, Vredenburgh J, Friedman A, Sampson J, Gururangan S, Rich J, Friedman H. A phase I trial of dasatinib (Sprycel) and erlotinib (Tarceva) for patients with recurrent malignant glioma. Neuro-oncology: OXFORD UNIV PRESS INC JOURNALS DEPT, 2001 EVANS RD, CARY, NC 27513 USA). 2008; 840-840.
43. Franceschi E, Stupp R, van den Bent MJ, van Herpen C, Laigle Donadey F, Gorlia T, Hegi M, Lhermitte B, Strauss LC, Allgeier A, Lacombe D, Brandes AA. EORTC 26083 phase I/II trial of dasatinib in combination with CCNU in patients with recurrent glioblastoma. Neurooncology. 2012; 14:1503-1510.

44. Lu-Emerson C, Norden AD, Drappatz J, Quant EC, Beroukhim R, Ciampa AS, Doherty LM, LaFrankie DC, Ruland S, Wen PY. Retrospective study of dasatinib for recurrent glioblastoma after bevacizumab failure. Journal of neuro-oncology. 2011; 104:287-291.

45. Agarwal S, Mittapalli RK, Zellmer DM, Gallardo JL, Donelson R, Seiler C, Decker SA, Santacruz KS, Pokorny JL, Sarkaria JN, Elmquist WF, Ohlfest JR. Active efflux of Dasatinib from the brain limits efficacy against murine glioblastoma: broad implications for the clinical use of molecularly targeted agents. Molecular cancer therapeutics. 2012; 11:2183-2192.

46. Agarwal S, Hartz AM, Elmquist WF, Bauer B. Breast cancer resistance protein and $\mathrm{P}$-glycoprotein in brain cancer: two gatekeepers team up. Current pharmaceutical design. 2011; 17:2793-2802.

47. Araujo J, Logothetis C. Dasatinib: A potent SRC inhibitor in clinical development for the treatment of solid tumors. Cancer Treatment Reviews. 2010; 36:492-500.

48. Costa DB, Kobayashi S, Pandya SS, Yeo WL, Shen Z, Tan W, Wilner KD. CSF concentration of the anaplastic lymphoma kinase inhibitor crizotinib. Journal of clinical oncology : official journal of the American Society of Clinical Oncology. 2011; 29:e443-445.

49. Hendricks BK, Cohen-Gadol AA, Miller JC. Novel delivery methods bypassing the blood-brain and blood-tumor barriers. Neurosurgical focus. 2015; 38:E10.

50. Darzynkiewicz Z, Gong J, Juan G, Ardelt B, Traganos F. Cytometry of cyclin proteins. Cytometry. 1996; 25:1-13.

51. Sauter ER, Nesbit M, Litwin S, Klein-Szanto AJ, Cheffetz S, Herlyn M. Antisense cyclin D1 induces apoptosis and tumor shrinkage in human squamous carcinomas. Cancer research. 1999; 59:4876-4881.

52. Liu X, Du L, Feng R. c-Src regulates cell cycle proteins expression through protein kinase $\mathrm{B} / \mathrm{glycogen}$ synthase kinase 3 beta and extracellular signal-regulated kinases 1/2 pathways in MCF-7 cells. Acta biochimica et biophysica Sinica. 2013; 45:586-592.

53. Zuryn A, Litwiniec A, Klimaszewska-Wisniewska A, Nowak JM, Gackowska L, Mysliwiec BJ, Pawlik A, Grzanka A. Expression of cyclin D1 after treatment with doxorubicin in the HL-60 cell line. Cell biology international. 2014; 38:857-867.

54. DiPaola RS. To arrest or not to G(2)-M Cell-cycle arrest : commentary re: A. K. Tyagi et al., Silibinin strongly synergizes human prostate carcinoma DU145 cells to doxorubicin-induced growth inhibition, G(2)-M arrest, and apoptosis. Clin. cancer res., 8: 3512-3519, 2002. Clinical 
cancer research : an official journal of the American Association for Cancer Research. 2002; 8:3311-3314.

55. Chumduri C, Gillissen B, Richter A, Milojkovic A, Overkamp T, Muller A, Pott C, Daniel PT. Apoptosis resistance, mitotic catastrophe, and loss of ploidy control in Burkitt lymphoma. Journal of molecular medicine (Berlin, Germany). 2015; 93:559-572.

56. Nakada $M$, Nakada $S$, Demuth $T$, Tran NL, Hoelzinger DB, Berens ME. Molecular targets of glioma invasion. Cellular and molecular life sciences : CMLS. 2007; 64:458-478.

57. Taurin S, Nehoff H, Greish K. Anticancer nanomedicine and tumor vascular permeability; Where is the missing link? Journal of Controlled Release. 2012; 164:265-275.

58. Ling GQ, Liu YJ, Ke YQ, Chen L, Jiang XD, Jiang CL, Ye W. All-trans retinoic acid impairs the vasculogenic mimicry formation ability of U87 stem-like cells through promoting differentiation. Molecular medicine reports. 2015; 12:165-172.
59. Lu KV, Chang JP, Parachoniak CA, Pandika MM, Aghi MK, Meyronet D, Isachenko N, Fouse SD, Phillips JJ, Cheresh DA, Park M, Bergers G. VEGF inhibits tumor cell invasion and mesenchymal transition through a MET/ VEGFR2 complex. Cancer Cell. 2012; 22:21-35.

60. Hunn MK, Farrand KJ, Broadley KW, Weinkove R, Ferguson P, Miller RJ, Field CS, Petersen T, McConnell MJ, Hermans IF. Vaccination with irradiated tumor cells pulsed with an adjuvant that stimulates NKT cells is an effective treatment for glioma. Clinical cancer research : an official journal of the American Association for Cancer Research. 2012; 18:6446-6459.

61. Vichai V, Kirtikara K. Sulforhodamine B colorimetric assay for cytotoxicity screening. Nature protocols. 2006; 1:1112-1116.

62. Taurin S, Allen KM, Scandlyn MJ, Rosengren RJ. Raloxifene reduces triple-negative breast cancer tumor growth and decreases EGFR expression. International journal of oncology. 2013; 43:785-792. 